\title{
Distribution patterns, population status and conservation of Melanosuchus niger and Caiman yacare (Crocodylia, Alligatoridae) in oxbow lakes of the Ichilo river floodplain, Bolivia
}

\author{
Ximena Aguilera ${ }^{1,2}$, Jorge S. Coronel ${ }^{1,2}$, Thierry Oberdorff ${ }^{4} \&$ Paul A. Van Damme \\ 1. Unidad de Limnología y Recursos Acuáticos (ULRA), Universidad Mayor de San Simón, Cochabamba, Bolivia. \\ 2. Laboratory of Aquatic Ecology, Katholieke Universiteit Leuven, De Beriotstraat 32, 3000 Leuven, Belgium; Jorge. \\ Coronel@bio.Kuleuven.be \\ 3. Asociación FaunAgua, Cochabamba, Bolivia; faunagua@yahoo.com \\ 4. Institut de Recherche pour le Développement (IRD), DMPA, Muséum National d'Histoire Naturelle, 43 rue Cuvier, \\ 75005 Paris, France; oberdorf@mnhn.fr
}

Received 05-III-2007. Corrected 25-IX-2007. Accepted 19-XI-2007.

\begin{abstract}
Caiman yacare (lagarto) and Melanosuchus niger (black caiman), sympatric species in the Bolivian Amazon basin, have been severely overexploited in the past. We present the results of a standardized survey of C. yacare and M. niger populations in order to evaluate their actual population status in twelve oxbow lakes of the Ichilo River floodplain. Additionally we explored the effect of environmental and anthropogenic variables on caiman distribution patterns. The average density of C. yacare and M. niger in the shoreline of floodplain lakes was of 6 and $1 \mathrm{ind} / \mathrm{km}$, respectively. For both species, the population was composed mainly of juvenile individuals. We used regression tree analysis (RTA) to assess patterns of M. niger and C. yacare densities with eight environmental and two anthropogenic variables. The RTA analysis showed that the variation in the densities of both C. yacare (52.4 \%) and M. niger (36.8 \%) was related to water conductivity. For C. yacare, higher densities occurred at higher values of water conductivity, while M. niger densities followed an opposite trend, resulting in relatively well spatially segregated populations of the two species. After excluding conductivity, Lake-River Distance (LRD) was shown to be the main splitting variable in the RTA analysis. The observed distribution patterns may be the result of the historical post-hunting situation, in combination with differences in habitat selection by the two species, and competitive exclusion processes between the two species. M. niger, a species reported to be recovering slowly from previous low population levels, appears relatively well protected in the Ichilo river floodplain. Rev. Biol. Trop. 56 (2): 909-929. Epub 2008 June 30.
\end{abstract}

Keywords: Bolivian Amazon, Caiman yacare, floodplain lakes, Melanosuchus niger.

Before the 1950s, the crocodilian species Melanosuchus niger (Spix, 1825) (black caiman) and Caiman yacare (Daudin, 1802) (locally called "lagarto") were widely distributed in the upstream Amazon basin in Bolivia, Perú, Ecuador, Colombia and Venezuela (Medem 1983, Ergueta and Pacheco 1990). From 1950, they became an important economic resource due to the high price of their skins (Ojasti 1996). The demand of crocodilian's skins, especially in European and North American markets, led to a massive overexploitation of $M$. niger first, and C. yacare afterwards (Ojasti 1996), provoking a considerable drop in population sizes and driving the former species to the border of extinction (Brazaitis 1989, Thorbjarnarson 1998). Besides hunting, other factors such as habitat perturbations caused by the wood extraction and deforestation for farming also contributed locally to their depletion (Abercrombie et al. 1982, Godshalk 1982).

In Bolivia, legal action to stop the crocodilian hunting was undertaken for the first time in 1961, when the authorities determined to 
forbid hunting between July and January each year. In 1967, a total prohibition for hunting was decreed, and later ratified in 1990 and in 1993, in agreement with international recommendations. $M$. niger, considered to be a species with a high risk of extinction by IUCN, was listed in Appendix I of CITES (Convention on International Trade in Endangered Species of Flora and Fauna). On the other hand, C. yacare, which was listed in Appendix II of Cites, in Bolivia was considered a species with a low risk of extinction by Pacheco and Aparicio (1996).

As a result of local and international conservation efforts, Melanosuchus niger recuperated slowly from previous low densities in areas with difficult access, such as remote oxbow lakes and marshy non-riverine wetlands (Pacheco and King 1995, Pacheco 1996, Liceaga et al. 2001, Llobet, pers. comm.). On the other hand, recent surveys of $C$. yacare populations in Bolivia revealed that this species has recovered in almost all areas of its original distribution, and particularly in the savanne lowland in the department of Beni (Pacheco and Llobet 1998, Aparicio et al. 1999). In 1999, after a decade of recuperation of $C$. yacare populations, Bolivian authorities modified national legislation, giving pace to a sustainable use of the species (Godshalk 1997, Llobet and Aparicio 1999, Llobet et al. 2004). Based on studies that showed its recovery in its original distribution range, cropping of $C$. yacare in the Amazonian departments of Beni, La Paz and Santa Cruz was legalized.

In the Ichilo river floodplain, C. yacare and $M$. niger are sympatric species (Medem 1983). Though King and Videz-Roca (1989) and Llobet and Goitia (1997) failed to find black caiman (M. niger) in this area, local indigenous people confirmed in 1998 that both species were still present in the inundated floodplains, the oxbow lakes and occasionally in the main river channels (Van Damme, unpubl. data). In this area, legal hunting of $C$. yacare is forbidden and illegal hunting for pelts is thought to be insignificant. The main threat to both species seems to be general human disturbance (such as navigation). Moreover, there is a general belief that accidental capture or drowning in commercial fishing nets represents a major impact on caiman populations; however this was never investigated in detail.

The objectives of this study were 1) to determine the population status of $C$. yacare and $M$. niger in the oxbow lakes of the Ichilo river flooding area; and 2) to assess the environmental and anthropogenic factors that influence the distribution and abundance of both species in the study area. This study aims to contribute to a better understanding of the influence of actual and historical disturbance on distribution patterns of caiman species in Bolivia, which is a prerequisite for the design of effective conservation strategies.

\section{MATERIALS AND METHODS}

Study area: the study was carried out in 12 oxbow lakes of the Ichilo river floodplain, situated between $16^{\circ} 40^{\prime} \mathrm{S}$ and $16^{\circ} 05^{\prime} \mathrm{S}$, and between $64^{\circ} 36^{\prime} \mathrm{W}$ and $64^{\circ} 53^{\prime} \mathrm{W}$. These coordinates embrace an area of approximately 1000 $\mathrm{km}^{2}$, which is ecologically defined as "riverine varzea forest" (Maldonado et al. 1996, Navarro and Ferreira 2000, Navarro and Maldonado 2002). The varzea forest is flooded annually during short intervals, through a polymodal and unpredictable flood pulse (Maldonado et al. 1996). During some years, the varzea forest does not inundate, and varzea lakes receive variable amounts of river water through channels which connect them with the main river (Bourrel et al. 1999). Oxbow lakes are characterized by variable amounts of emergent macrophytes, locally called tarope (Eichornia azurea) and yomomo (Cyperus cf. giganteus).

Puerto Villarroel, situated at $16^{\circ} 49^{\prime} \mathrm{S}$ and $64^{\circ} 47^{\prime} \mathrm{W}$ on the Ichilo riverbank, is one of the most important fishery ports in Bolivia. Ninety five percent of the annual catch of the commercial fishermen, which fluctuates between 30 and 60 tons, is captured downstream between the town of Puerto Villarroel and the confluence of the Ichilo and Grande rivers. Eighty five percent of the annual catch 
is captured in the river channel, and the rest is captured in floodplain lakes (Van Damme, unpubl.). Indigenous people possess property rights over their territory on the left bank of the river, but only few floodplains in their Indigenous Territory are effectively protected against entering commercial fishermen.

Caiman data: nocturnal spotlight counts of caimans ( $M$. niger and $C$. yacare) were conducted in the study area between October and December in 1999 and in December 2000. In total, $68 \mathrm{~km}$ were sampled in 1999, and 48 $\mathrm{km}$ in 2000 . The survey methods were based on Pacheco (1996) and Llobet and Goitia (1997). Both easily accessible oxbow lakes and remote oxbow lakes with difficult access were sampled. Because it was not possible to survey all the perimeter of each lake, randomly selected stretches were surveyed. On each lake, four transects of $1 \mathrm{Km}$ were carried out using routes measured by a handheld global positioning system (GPS). The counts of crocodilians in the oxbow lakes were conducted using an aluminum canoe, from which caimans and alligators were located, using a 12 volt hand light. Transects were traversed before dark to record habitat and navigational hazards. Inclement weather and periods of elevated water levels were avoided. Counts were expressed as ind/ $\mathrm{km}$ of shoreline (Pacheco 1996). In this paper, "black caiman" refers to $M$. niger, whereas "lagarto" refers to C. yacare. We distinguished both species by the shape of the skull (i.e. $M$. niger has distinctly larger eyes, and a narrower snout than C. yacare ) and, upon approaching more closely, by the difference in skin color (as its name indicates $M$. niger is darker than C. yacare).

Caimans were approached as closely as possible, in order to estimate their total length (Brazaitis 1989). We estimated the total length of the specimen (from the anterior tip of the snout-vent to the posterior tip of the tale) based on the size of the skull. We used for this the approach based on the relationship between the length of the skull and the total length of the body (Magnusson 1983, Cisneros and Van
Damme 2005). During the present study, some juvenile individuals were captured and measured. Cisneros and Van Damme (2005) and Cisneros (unpubl. data) tested the reliability of this method through the capture of 31 individuals of all size classes. According to their lengths, $C$. yacare were classified in four year classes: I (neonates; $<0.50 \mathrm{~m}$ ), II (juveniles; $0.50<\mathrm{x}<1.2 \mathrm{~m}$ ), III (subadults; $1.2<\mathrm{x}<1.8 \mathrm{~m}$ ), and IV (adults; $\mathrm{x}>1.8 \mathrm{~m}$ ), whereas $M$. niger individuals were classified in year classes I (neonates; $<0.50 \mathrm{~m}$ ), II (juveniles; $0.50<\mathrm{x}<1.2$ $\mathrm{m}$ ), III (subadults; $1.2<\mathrm{x}<2 \mathrm{~m}$ ), and IV (adults; x>2 m) (Ayarzaguena 1983, Pacheco 1990).

Environmental variables: the minimum distance between each oxbow lake and the main channel of the Ichilo River (Lake-river distance; LRD) was calculated using LANDSAT satellite images. Connection of lakes and river channel by creeks was not taken into account because of lack of information. Walking time (variable TIME) was the time spent to walk from the river to the lake at normal walking speed. The perimeter (variable PERI) and surface (variable SUPE) of the oxbow lakes were calculated from digitized topographical maps at a scale of 1:50 000 (year 1988) that were corrected by LANDSAT satellite images of the year 2000. Shore Line Development (SLD) of oxbow lakes was calculated in order to provide additional information on lake morphology. SLD was calculated as $\mathrm{D} / 2 \mathrm{~V}$ pi A, where $\mathrm{D}$ is the lake perimeter and $\mathrm{A}$ is the lake surface. Digitalization and automated calculation of perimeters and surfaces were carried out by ILWIS software. Six additional local environmental variables were measured at each oxbow lake: mean lake depth (m) (variable PRME), maximum lake depth (m) (variable PRMA), water transparency (cm Secchi depth) (variable TRAN), water conductivity $(\mu \mathrm{S} / \mathrm{cm})$ (variable COND), $\%$ of cover with tarope (Eichornia azurea) (variable TARO) and $\%$ of cover with yomomo (Cyperus cf. giganteus) (variable YOMO). Macrophyte cover (the percentage of the total lake surface covered by either tarope or yomomo) was estimated by visual observation. 
Anthropogenic variables: fishing data from commercial fishermen of Puerto Villarroel from three consecutive years (1998-2000) were analyzed in order to quantify accidental capture rates of crocodilians in nets in the Ichilo River basin. The fisheries data allowed the computation of the number of days fishermen used gill nets, as opposed to other fishing methods, such as hooks, fishing lines or harpoon. Emphasis was given to gill net data because gill netting is the only method that leads to accidental crocodilian mortality. Data on the number of caimans drowned in fishing nets in oxbow lakes were extracted from fisheries data collected by the fishermen.

Fisheries data allowed computation of annual fishery effort in individual oxbow lakes. In 1998, all fishermen of PuertoVillarroel together fished 5355 man-days, in 19996 638 man-days and in 20004341 man-days. Commercial Fisheries Disturbance (variable CFD) of lakes was defined as the number of man-days that fishermen entered the lakes. We used CFD as a general indicator of human disturbance of caiman populations provoked by external people entering the area. CFD is thought to reflect both the disturbance caused by accidental drowning of caimans in fishing nets and general disturbance caused by presence of humans.

Apart from commercial fisheries, caiman populations in oxbow lakes may also be disturbed by the indigenous people themselves that use the lakes for subsistence fishing. The visiting intensity of lakes by indigenous people was estimated as the number of permanent canoes recorded (variable CANO) in lakes.

Data analysis: Pearson correlation test was used to test correlations between environmental and anthropogenic variables. A Canonical Correspondence Analysis (CCA) was conducted to identify the relative importance of environmental and human factors in explaining caiman distribution patterns. CCA selects the linear combination of environmental variables that maximizes the dispersion of the caiman scores (Jongman et al. 1987). The
CCA allowed for simultaneous representation of sampling sites, explanatory variables and species class centroids in a reduced ordination space of orthogonal axes. Subsequently, associations between $C$. yacare and $M$. niger densities (all size classes and averaged between the two years) and the set of explanatory variables were evaluated using regression tree analysis (RTA), a binary partitioning technique (Breiman et al. 1984). For each partition, RTA picks the variable that minimizes the residual sum of squares (RSS) of the two subgroups, relative to the parent group. The values of the selected explanatory variable over each subset define a splitting threshold, and the mean of the dependent variable values in each subgroup is the predicted value for this subgroup. This process is recursively and independently continued on each subgroup, checking all divisions and variables, until additional splits provide minor further reduction in the RSS. Environmental variable TRAN was excluded from this analysis due to a missing value for lake "Los Limones". The minimum number of lakes allowed in each node was four.

The available caiman data were used to estimate the number of caimans in oxbow lakes that were not visited during the survey (total sample size $=159$ ). For this purpose, RTA analyses on the lagarto (C. yacare) data were re-assessed without entering conductivity (COND) and tarope cover (TARO) (the two first splitting variables) in the models, as these two variables were not available for most of the 159 oxbow lakes. The mean density values obtained for each split in the trees were then used to calculate densities for both $C$. yacare and M. niger in the 159 lakes. The main Ichilo river channel and clear-water tributaries Ibabo, Useuta and Landivar were excluded from the analysis. All statistical analyses were performed using STATISTICA 6.0 and SYSTAT 9.

\section{RESULTS}

Counts and population structure of $C$. yacare and M. niger: in 1999, 58 black caimans and 341 lagartos were counted in the 
12 surveyed oxbow lakes, whereas in 2000 a total of 34 black caimans and 297 lagartos were encountered. In both years, only four of twelve (33\%) sampled lakes contained $M$. niger, whereas C. yacare was observed in all of them. In both years, the $87.4 \%$ were lagartos, and the remaining $12.6 \%$ were black caimans.

During 1999, the highest density of juvenile, subadult and adult C. yacare recorded in an oxbow lake was $10.5 \mathrm{ind} / \mathrm{km}$ of shoreline (oxbow lake Corte Chori), and the highest density of $M$. niger was $6.8 \mathrm{ind} / \mathrm{km}$ of shoreline (in the oxbow lake of Capernaúm). In the year 2000, the highest density of $C$. yacare was 7.3 $\mathrm{ind} / \mathrm{km}$ of shoreline (Corte Pistola oxbow lake), whereas the highest density of $M$. niger was 4.8 ind $/ \mathrm{km}$ of shoreline (in oxbow lake Las Flores II) (Table 1). In the main channel of the Ichilo River, the population density of C. yacare was $6 \mathrm{ind} / \mathrm{km}$ of shoreline in 1999, which was in the same range as the density of this species in nearby lakes. Black caimans were absent in the main river channel in 1999.

In both years, of all lagartos recorded in the oxbow lakes, $40 \%$ were class I individuals in contrast to the $8 \%$ of all black caimans (Fig. 1). The distribution of newly born caimans generally followed the distribution patterns of subadults and adults, C. yacare newborns being found in most of the oxbow lakes, whereas $M$. niger newborns were only found in remote lakes, and were strongly correlated with adult individuals of the same species (Pearson correlation; $\mathrm{r}=0.97, \mathrm{p}<0.0001)$. After excluding group I individuals of $M$. niger, $78 \%$ of individuals in 1999 and $65 \%$ of individuals in 2000 (Fig. 1) belonged to class II. In 1999, most of the C. yacare belonged to year class II (53\%), whereas in 2000 , more $C$. yacare belonged to size class III (51\%) (Fig. 1). In both species,

\section{C. yacare}
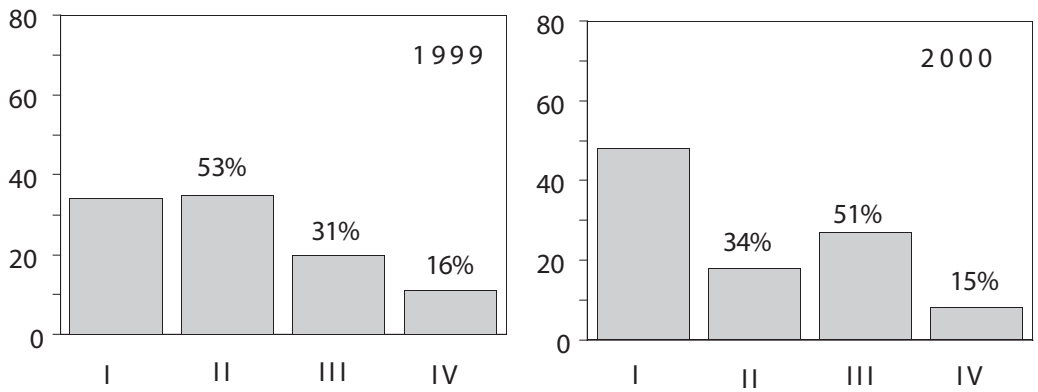

M. niger
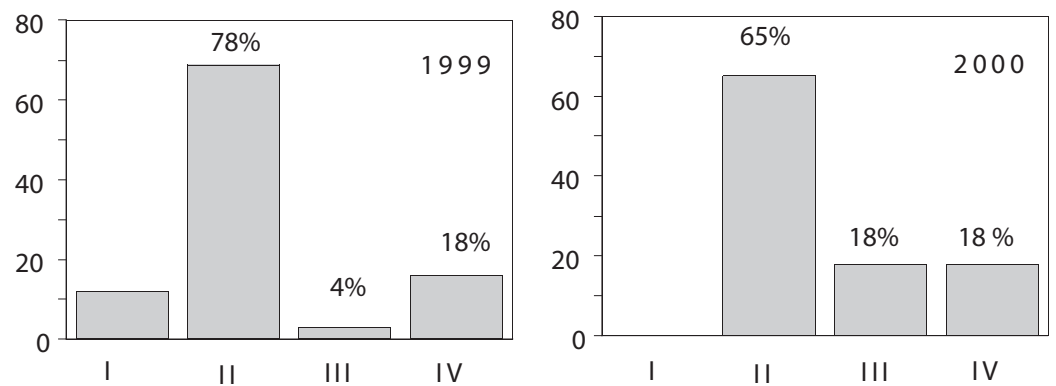

Fig. 1. Size frequencies of C. yacare and M. niger in oxbow lakes of the Ichilo river floodplain (pooled data of 1999 and 2000). Size classes are defined in Material and Methods. The value above each bar represent the proportion of crocodiles of groups II, III and IV after excluding newborns (group I). 


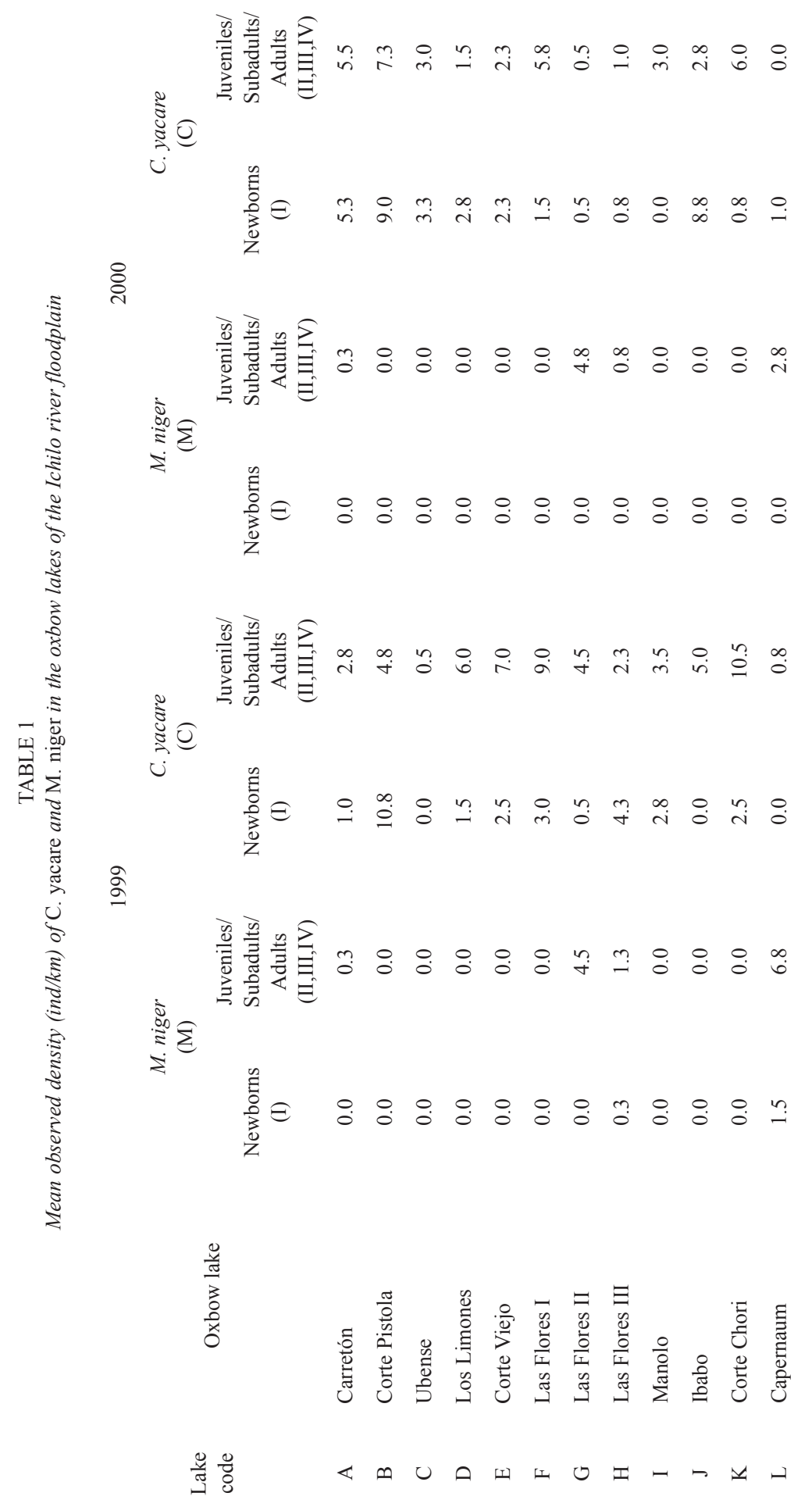


adult individuals (class IV) were relatively rare, always representing less than $20 \%$ of the total of juveniles, subadults and adults.

Environmental factors: the Pearson correlation between the explanatory variables measured in the 12 lakes surveyed (Tables $2,3)$ revealed that percentage of cover with yomomo (YOMO) was positively correlated with Lake-River Distance (LRD), showing that remote lakes had a higher macrophyte cover, coinciding with a higher water transparency. Both mean lake depth and maximum depth were not significantly different between lakes close to the river and remote lakes. Walking time (TIME) was highly correlated to LakeRiver Distance $(\mathrm{LRD})(\mathrm{r}=0.83, \mathrm{p}<0.01)$ and was omitted from further analysis. The correlation between LRD and lake surface area was not significant $(p>0.05)$, meaning that there were no large differences in size between lakes close to the river channel and remote lakes. There was a negative non-significant correlation between Lake-River Distance (LRD) and Conductivity (COND), suggesting that lakes with a high conductivity are close to and in permanent connection with the main river channel. Coincidentally, there is a correlation between the variable COND and the number of canoes (CANO) in each lake. This is not surprising since local people usually enter in lakes that are close to the main river channel.

Effects of environmental and anthropogenic variables on caiman distribution patterns: CCA (direct gradient analysis) showed a strong association between caiman scores and environmental variables (Fig. 2). The first two axes explained together $89 \%$ of the total variance in the caiman data as explained by the environmental variables, the sum of the canonical eigenvalues being 0.64 . The projection of the variables on the axis of variable water transparency (TRAN), Lake-River distance (LRD) and macrophyte Cyperus cover (YOMO) shows that $M$. niger is mainly found in lakes with the highest values for these variables, whereas $C$. yacare was mainly found in lakes close to the river, characterized by low water transparency, high conductivity (COND), higher commercial fisheries disturbance (CFD) and high tarope cover (TARO). There is also a

TABLE 2

Pearson Correlation Matrix of the twelve explanatory variables

\begin{tabular}{|c|c|c|c|c|c|c|c|c|c|c|c|c|}
\hline & PERI & SUPE & LRD & TIME & PRME & PRMA & TRAN & COND & TARO & YOMO & CFD & CANO \\
\hline PERI & 1.00 & & & & & & & & & & & \\
\hline SUPE & 0.62 & 1.00 & & & & & & & & & & \\
\hline LRD & -0.23 & -0.23 & 1.00 & & & & & & & & & \\
\hline TIME & -0.26 & 0.01 & 0.83 & 1.00 & & & & & & & & \\
\hline PRME & 0.27 & 0.01 & -0.37 & -0.45 & 1.00 & & & & & & & \\
\hline PRMA & 0.25 & 0.02 & -0.57 & -0.58 & 0.89 & 1.00 & & & & & & \\
\hline TRAN & 0.04 & 0.24 & 0.46 & 0.39 & 0.12 & -0.07 & 1.00 & & & & & \\
\hline COND & 0.45 & 0.16 & -0.37 & -0.42 & -0.23 & -0.25 & -0.28 & 1.00 & & & & \\
\hline TARO & 0.19 & -0.10 & -0.30 & -0.47 & 0.51 & 0.58 & -0.35 & 0.09 & 1.00 & & & \\
\hline YOMO & -0.32 & 0.13 & 0.70 & 0.76 & -0.32 & -0.42 & 0.70 & -0.43 & -0.31 & 1.00 & & \\
\hline CFD & 0.49 & 0.29 & -0.43 & -0.54 & 0.51 & 0.50 & -0.26 & 0.13 & 0.66 & -0.44 & 1.00 & \\
\hline CANO & 0.78 & 0.57 & -0.17 & -0.16 & -0.18 & -0.25 & 0.04 & 0.80 & -0.14 & -0.17 & 0.14 & 1.00 \\
\hline
\end{tabular}

Numbers in bold are statistically significant. Abbreviations of variables are given in the text and in Tables 2 and 3. 


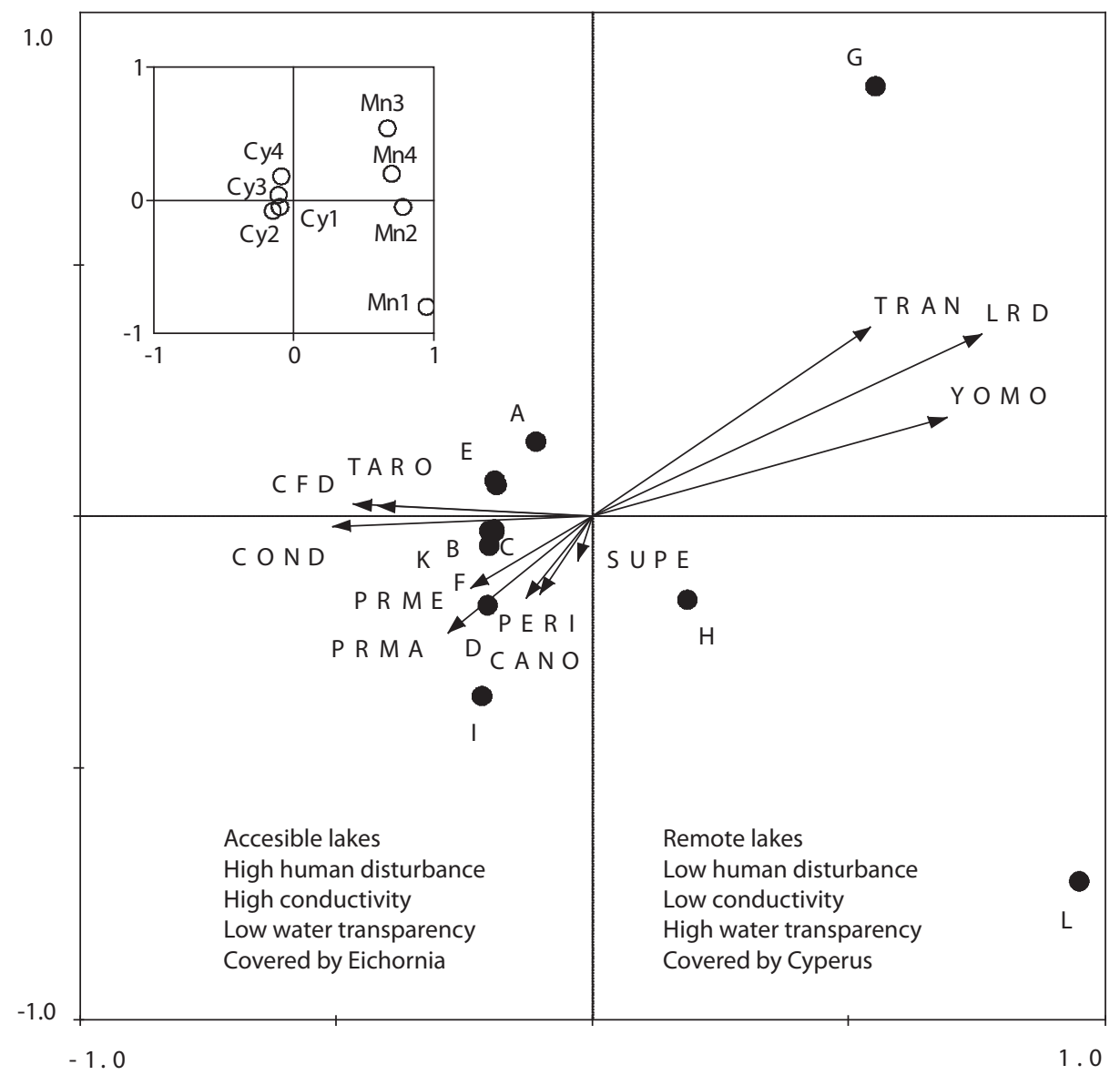

Fig. 2. CCA ordination biplot of oxbow lakes in the Ichilo river floodplain and environmental variables. Caiman scores in the plane formed by the same canonical axes are shown in inset $(\mathrm{Cy}=C$. yacare; $\mathrm{Mn}=M$. niger $)$. The lakes $\mathrm{L}$ (Capernaum), G (Las Flores II), H (Las Flores III) and A (Carreton) harboured M. niger in decreasing abundance. All the other lakes only harboured C. yacare. Lake codes are given in Annex 1. Data points for species size groups are shown in the insert.

weak size gradient for black caiman; however there was no clear correlation with environmental variables. The projection of the lakes on the same plane shows a separation of lakes close to the river, dominated by all size classes of C. yacare, and remote lakes, with various proportions of $C$. yacare and $M$. niger. However, it should be noticed that, due to the small sample size used, the global CCA model was not statistically significant.

The Regression Tree Analysis (RTA) divided the observations of $C$. yacare into two groups according to water conductivity values less than $59 \mu \mathrm{S} / \mathrm{cm}\left(\mathrm{CY} 1_{\mathrm{a}}\right)$ and greater than
$59 \mu \mathrm{S} / \mathrm{cm}\left(\mathrm{CY} 2_{\mathrm{a}}\right)$ and explained $52.4 \%$ of the variation in densities (Fig. 3). The RTA divided the observations of $M$. niger into two groups according to LRD values less than $1.55 \mathrm{~km}$ (MN1) and greater than $1.55 \mathrm{~km}(\mathrm{MN} 2)$ and explained $52.6 \%$ of the variation in densities (Fig. 4B). Corresponding C. yacare densities for groups $\mathrm{CY} 1_{\mathrm{a}}$ and $\mathrm{CY} 22_{\mathrm{a}}$ were, respectively, 3.88 and $9.42 \mathrm{ind} / \mathrm{km}$, whereas mean $M$. niger densities for groups $\mathrm{MN} 1$ and $\mathrm{MN} 2$ were, respectively, 0.00 and $2.88 \mathrm{ind} / \mathrm{km}$.

In remote lakes where $M$. niger was present, C. yacare reached relatively lower densities (Table 1). Combining the data obtained in 


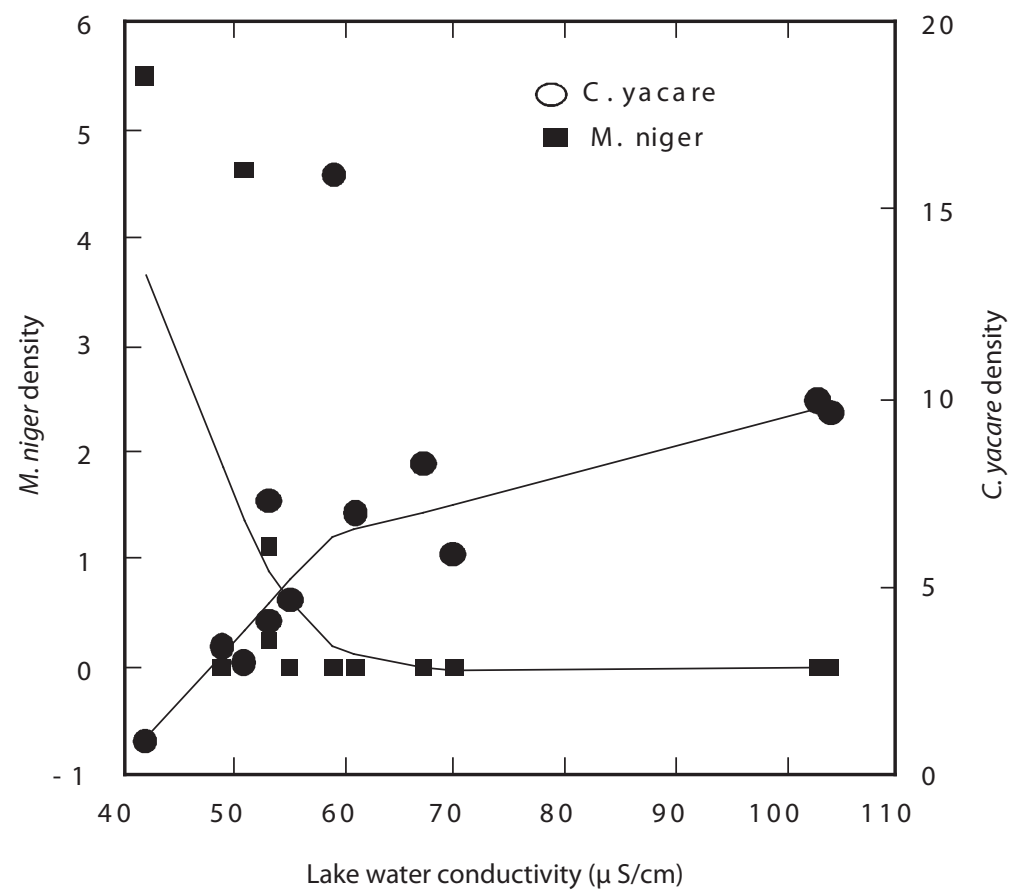

Fig. 3. Density of juvenile, subadult and adult C. yacare (white dots) and M.niger (black squares) in floodplain lakes of the Ichilo river as a function of lake water conductivity (main predicting variable in the Regression Tree Analysis). Data for 1999 and 2000 were pooled. Lines are LOWESS trend lines, tension=0.8.

1999 and 2000, there was a significant negative correlation between the two species densities (Pearson Correlation; $\mathrm{r}=-0.60, \mathrm{p}<0.05$ ).

Use of oxbow lakes by commercial and indigenous fishermen: in the study area, 159 oxbow lakes were identified using a LANDSAT image of August 2000. A few lakes have a permanent connection with the river channel, but most of them are not connected with the river channel at least during part of the year. The mean distance between oxbow lakes and river channel (LRD) was $1.15( \pm 0.96) \mathrm{km}$ (Table $3)$. The mean perimeter of the lakes was 3.22 $( \pm 3.50) \mathrm{km}$ (Table 3$)$, the mean surface 0.28 $( \pm 0.42) \mathrm{km}^{2}$. Most of the oxbow lakes were elongated and curved with an average Shore Line Development of $1.94( \pm 0.73) \mathrm{Km}$.

Generally, fishermen in the period 19982000 had a preference for oxbow lakes situated close to the river channel and for large-sized oxbow lakes. The perimeter of lakes that were visited during this period by fishermen was $5.87( \pm 5.32) \mathrm{km}$, the mean Lake-River Distance (LRD) for visited lakes was 0.56 $( \pm 0.43 \mathrm{~km})$, well below the LRD value for all lakes (Table 3). More than $95 \%$ of the lakes visited by the fishermen in 1999 and 2000 had a Lake-River Distance shorter than $1.25 \mathrm{~km}$ (Fig. 4A). Lake Perimeter was significantly larger for visited lakes than for non-visited lakes, whereas Lake-River Distance of the former was significantly smaller (ANOVA) (Table 3).

The Commercial Fisheries Disturbance (CFD) and the number of canoes (CANO) in each of the 12 lakes (Annex 2) showed that in the three lakes controlled by indigenous people (Las Flores II, Las Flores III, Capernaum), commercial fishermen never entered. Five lakes (Carretón, Ubense, Los Limones, Corte Viejo, and Corte Chori) received a fisheries impact 


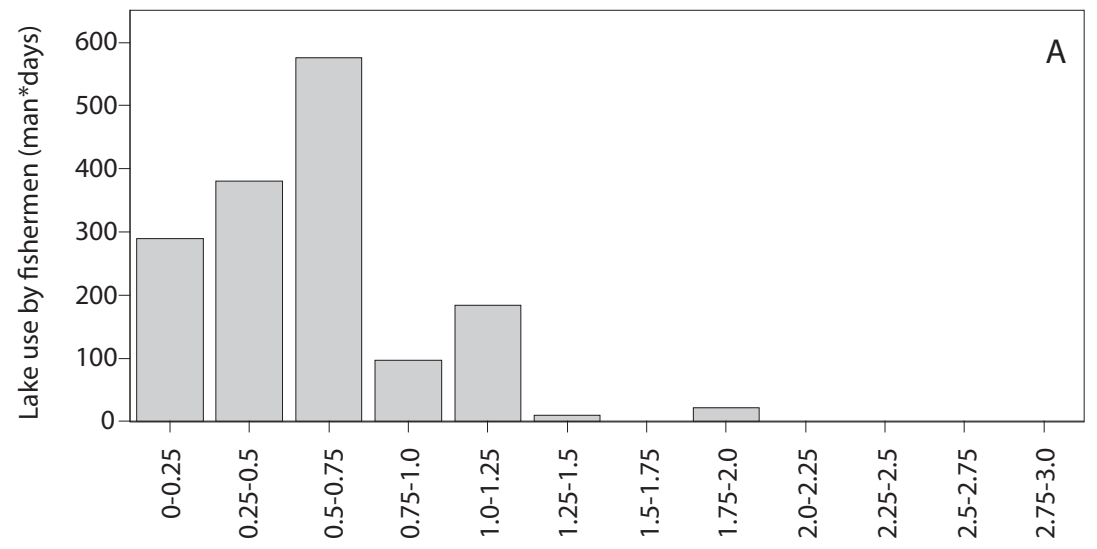

Distance lake-river $(\mathrm{km})$

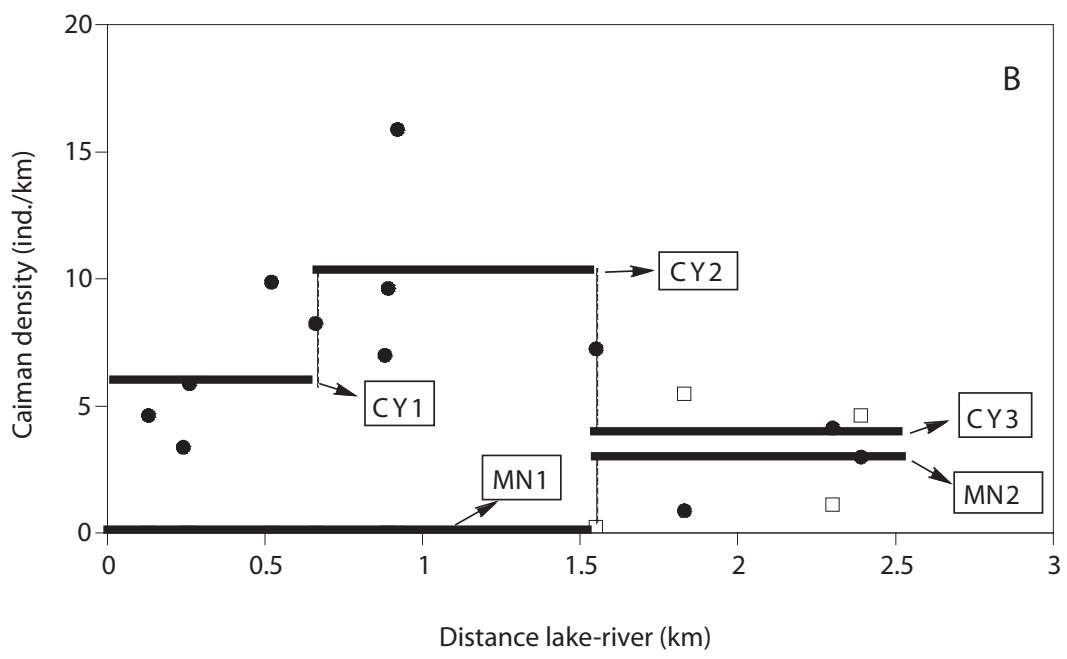

Fig. 4. (A) Oxbow lake use by fishermen in relation to river-lake distance; (B) Density of C. yacare (black dots) and M.niger (white squares) in twelve floodplain lakes of the Ichilo river in function of river-lake distance. Data for 1999 and 2000 were pooled. The CY and MN groups determined by Regression Tree Analysis are indicated.

of more than 100 man-days between 1998 and 2000. For the lake sample, no significant correlation was found between Commercial Fisheries Disturbance (CFD) and Lake-River Distance (LRD) $(\mathrm{r}=-0.43, \mathrm{p}>0.05)$ (Table 2), showing that factors other than accessibility also influenced fishermen's behaviour.

The presence of canoes (CANO) in the lakes at the time of study which reflects lake use by local indigenous people, was not significantly correlated with lake-river distance $(\mathrm{r}=-0.17, \mathrm{p}>0.05)$, but positively correlated with lake perimeter $(\mathrm{r}=0.78, \mathrm{p}<0.01)$ (Table 2$)$. CANO and CFD were not correlated $(r=0.14$, $\mathrm{p}>0.05$ ). The absence of any path between the river and lakes Corte Pistola and Las Flores II showed that these lakes, of all the lakes visited during the present study, received the lowest impact by humans.

Importance of accidental captures of $M$. niger and $C$. yacare by commercial fishermen; estimation of the number of caimans in 159 oxbow lakes: the number of $C$. yacare 
TABLE 3

Average Lake-River Distance (LRD) and average Lake Perimeter (LP) for lakes that were visited and for lakes that were not visited by commercial fishermen in 1999 and 2000

$\begin{array}{lccccc} & \mathrm{N} & \begin{array}{c}\text { LRD }(\mathrm{km}) \\ ( \pm \mathrm{SD})\end{array} & \text { ANOVA } & \begin{array}{c}\text { LP }(\mathrm{km}) \\ ( \pm \mathrm{SD})\end{array} & \text { ANOVA } \\ \text { All lakes } & 159 & 1.15 \pm 0.96 & - & 3.22 \pm 3.50 & - \\ \text { Lakes used by fishermen } & 34 & 0.56 \pm 0.43 & \begin{array}{c}\mathrm{F}=17.9 \\ (\mathrm{p}<0.001)\end{array} & 5.87 \pm 5.32 & \begin{array}{c}\mathrm{F}=29.10 \\ (\mathrm{p}<0.001)\end{array} \\ \text { Lakes not used by fishermen } & 125 & 1.31 \pm 1.00 & & 2.50 \pm 2.38 & \end{array}$

accidentally caught by fishing nets was 49 in 1998, 49 in 1999, and 24 individuals in 2000; only five $M$. niger were caught, three individuals in 1998 and two individuals in 2000 (Table 4). According to these data it was calculated that for each 32 fishing days one $C$. yacare was accidentally trapped in fishing net. In the case of $M$. niger, one individual was trapped each 332 fishing days.

Applying a RTA analysis on the lagarto data without entering conductivity (COND) and tarope cover (TARO) as independent variables, LRD became the predicting variable for $C$. yacare. Three groups were formed: at LRD $<0.66 \mathrm{~km}$ the $C$. yacare density was 3.82 , at LRD between 0.66 and $1.55 \mathrm{~km}$ the estimated C. yacare density was 10.19 and at $\mathrm{LRD}>1.55$ the estimated density was 5.94 (Fig. 4B). The explained variance at the first split was $33.9 \%$, and at the second split $27.4 \%$. Using these $C$. yacare thresholds and the LRD-tresholds for $M$. niger shown in Fig. $4 \mathrm{~B}$, the total population of subadults and adults of $M$. niger in the study area (only considering the 159 oxbow lakes) was estimated at 359 individuals, whereas the population estimation for C. yacare was 3984 individuals. When newborns were excluded, the estimated number of $M$. niger and $C$. yacare was, respectively, 232 and 2373 . The total mortality of $C$. yacare in the oxbow lakes of the area during the 3 year period represented 5.4\% of the estimated total of this species, whereas for $M$. niger it was $2.5 \%$ of the estimated total (resp. 9.1\% and 3.9\% when newborns are excluded from the analysis). Whereas $16 \%$ of all the caimans in the sampled area were black caimans, only $4 \%$ of the caimans caught in fishing nets belonged to this species.

Estimations by fishermen of the length of drowned C. yacare revealed that $7.5 \%(\mathrm{~N}=4)$ belonged to size class II, $41.5 \%(\mathrm{~N}=22)$ to size class III and $50.9 \%(\mathrm{~N}=27)$ to size class IV. Two of the five $M$. niger that drowned in the fishing nets were reported to belong to size class III, and two of them belonged to size class IV. There is an under representation of smallersized $C$. yacare and $M$. niger in the bycatch.

\section{DISCUSSION}

C. yacare and $M$. niger population status: recent surveys conducted in different localities in South America indicate that $C$. yacare seems to have recovered throughout most of its historical distributional range (Scott et al. 1990, Waller and Micucci 1993, King et al. 1994). In Bolivia, high numbers of this species have been recorded by King and VidezRoca (1989), Pacheco (1990) and Aparicio et al. (1999) in the lowlands of the department of Beni, and, more recently, high densities were found all over tropical lowland Bolivia (Llobet et al. 2004). The present study area is not an exception and confirms existing trends: Llobet and Goitia (1997), who undertook a year-round study in the present study area, found that the the Ichilo river seems to contain a healthy 


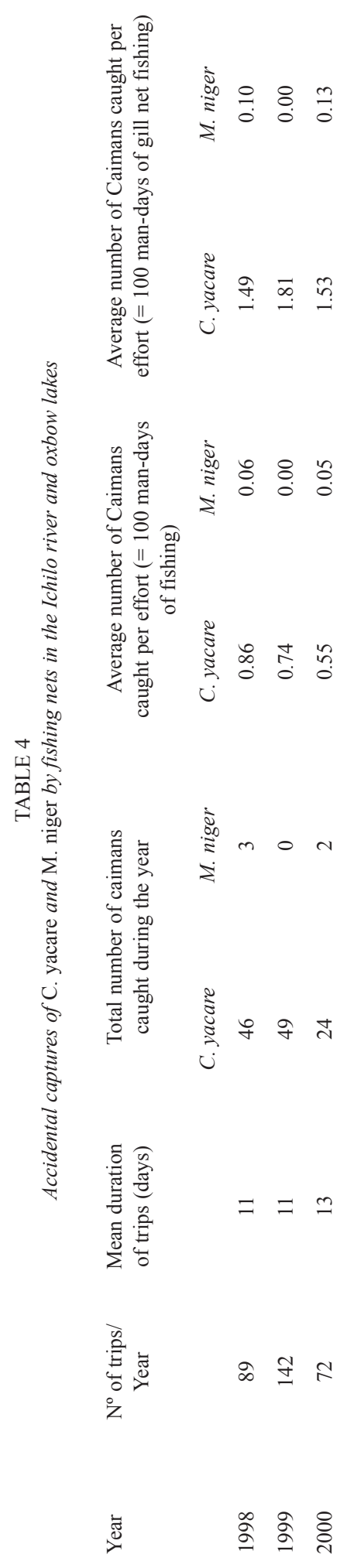

population distributed widely over its varzea lakes and main channel. The recovery of this species in the Amazonian white-water floodplains is thought to be the result of fast growth, high reproduction rates, and easy adaptation to the savanne lowlands, oxbow lakes and main river channels (Llobet et al. 2004). Brazaitis (1989) suggested that in these areas food is readily available for a vast lagarto population. The Ichilo river floodplain is a well protected area and probably offers optimal growing conditions for this species.

The Bolivian population of $M$. niger, on the other hand, was already greatly reduced when in the 1970's local and international authorities decided to prohibit trade. Monitoring of populations established that $M$. niger was greatly reduced in four of the seven countries of their natural distribution (Thorbjarnarson 1998). In Bolivia, surveys of $M$. niger, carried out in 1986 and 1987, evidenced that this species was still found in small numbers in many localities (King and Videz-Roca 1989); moreover, most individuals registered belonged to juvenile classes. Pacheco (1993), who counted M. niger in certain areas in Beni (north Bolivia), recorded densities below $19 \mathrm{ind} / \mathrm{km}$ in lakes and $1 \mathrm{ind} /$ $\mathrm{km}$ in river channels. Surveys conducted in the Blanco and the Negro rivers in the department of Santa Cruz (north-east Bolivia) revealed densities of $1 \mathrm{ind} / \mathrm{km}$ of shoreline (RebolledoGarin and Tapia-Arauz 1994). Liceaga et al. (2001) recorded densities of $0.4 \mathrm{ind} / \mathrm{km}$ in old river arms connected with the Iténez River. These data show that remanent populations of $M$. niger species were present in the more remote areas of the Amazon basin, however in vast areas their density was, and probably still is, extremely low. The relatively long time needed by this species for recruiting reproductive individuals (Rebêlo and Magnusson 1983) may explain its slow recovery in Bolivia. The competition for food resources with previously established C. yacare, as was recorded by Vallejo et al. (1996), may make recovery even more difficult.

Llobet and Goitia (1997) suggested that $M$. niger was absent in the Ichilo river basin, but 
this was probably because their survey did not include remote lakes, where this species seems to be confined. During the present study, local indigenous knowledge provided the basis for the localization of $M$. niger in the less accessible lakes.

Distribution patterns of $C$. yacare and $M$. niger: our data reveal occurrence of habitat partitioning between C. yacare and M. niger, as was reported in other parts of the Amazon (Magnusson 1985, Herron 1994, Rebêlo and Lugli 2001). According to Otte (1978), Medem (1983) and Herron (1994), black caiman prefers slow-moving waters and the isolated, generally deeper, oxbow lakes. Da Silveira and Thorbjarnarson (1999) stated that black caiman prefer heavily vegetated and remote interior lake systems. C. yacare seems to be less selective, and can be found in oxbow lakes, marshes, river channels and small creeks. However, it should be emphasized that many of the published statements on habitat selection of either species may reflect post-hunting situations (Magnusson 1982, 1985). In a nearly pristine oxbow lake in Manu National Park (Peru), both species were present in almost equal proportions, however were spatially segregated (Herron 1994).

Apart from the observations made by Herron (1994), there exist no data that suggest which of the two sympatric species was dominant in the past. Present-day C. yacare populations might be stronger in the lakes where $M$. niger was intensively hunted in the past (accessible areas), whereas in areas where relict post-harvest populations of $M$. niger remained (most probably in remote lakes with difficult access), the latter might have out-competed C. yacare. Following this hypothesis, the present distribution patterns would still reflect the burden of historical harvesting. Probably, C. yacare has been able to recover faster in oxbow lakes with easy access as a result of low post-harvest levels of $M$. niger, combined with the higher recovery potential of the former species (Fig. 5). Unpublished data on caimans in the main channel of the Ichilo river in 1999 indicated the presence of $C$. yacare in all the transects, whereas no caimans were registered,
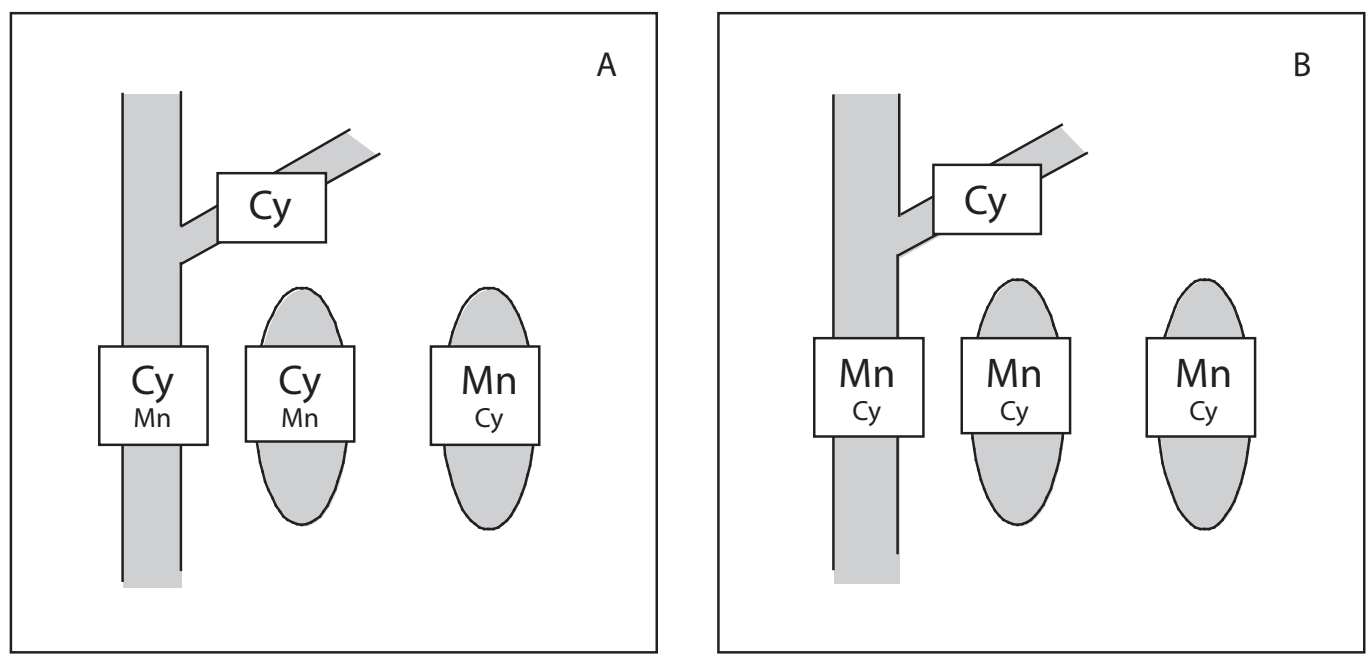

Fig. 5. Schematic diagram of the Ichilo river floodplain, showing the main river channel, a side river, an oxbow lake close to the river and an inland, remote oxbow lake. The two diagrams show possible climax distribution patterns: (A) Melanosuchus niger $(\mathrm{Mn})$ is dominant in the remote lakes, whereas C.aiman yacare $(\mathrm{Cy})$ is dominant in the rivers and in the lakes close to the river. This pattern might result from habitat segregation, and coincides with the present-day distribution pattern; (B) Melanosuchus niger is dominant in all larger water bodies, and C. yacare is pushed away to smaller river channels and specific microhabitats in lakes. 
nevertheless indigenous people confirm to have observed occasional adult caimans in the river channel.

In the present study, there is some evidence that the distribution patterns of $C$. yacare and $M$. niger in the Ichilo river floodplain are influenced by lake characteristics. Black caiman seems dominant in far-away, clear water lakes covered by Cyperus cf. giganteus, whereas $C$. yacare seems predominant in accessible lakes located at a small distance of the river channel and characterized by low transparency. The regression tree analysis showed that one single variable (conductivity) was able to explain a high percentage of the variability in caiman densities encountered. Water conductivity is probably not the causal factor of observed distribution patterns, but co-varies with other variables indicative of the degree of isolation of remote lakes, such as water transparency and macrophyte cover.

The spatial segregation between $C$. yacare and $M$. niger may occur both between lakes and within lakes. In the latter case, segregation may result from within-lake microhabitat heterogeneity, not measured during the present study. Similar as was found by Herron (1994), C. yacare was always present in remote lakes, even in the ones where $M$. niger reached relatively high densities (Capernaum, Las Flores II), and this may be the result of the species selecting other microhabitats than $M$. niger. The fact that the relative number of $C$. yacare found in lakes dominated by $M$. niger was lower than reported in a Peruvian oxbow lake by Herron (1984) may be the result of the present survey method which might not have detected clusters of $C$. yacare in lake edges.

On the other hand, caiman distribution may be the result of competitive exclusion between the two species, though present-day distribution patterns may have been molded additionally by historical hunting processes. Medem (1983) argued that in the absence of $M$. niger, $C$. yacare occupies most of the locally available aquatic habitats, however, in the presence of adult $M$. niger, $C$. yacare occupies only the shallower oxbow lakes, presumably to avoid being preyed upon by the former or, alternatively, as a result of being excluded from its preferred microhabitats. Several authors indicated that in the long term, and in the absence of humans, $M$. niger may out-compete C. yacare (Magnusson 1982, Magnusson and Rebêlo 1983). The generally higher $M$. niger densities found in the more remote lakes during the present study may support this assumption. According to this hypothesis, the larger and more dominant species, $M$. niger, will gradually exclude the smaller species, $C$. yacare, and a new stable equilibrium will occur once all the oxbow lakes are occupied predominantly by $M$. niger. This latter species, being a strong competitor, might also become dominant in the main river channels. C. yacare then might be obliged to retreat to a niche which is much narrower than the one it occupies nowadays. Nevertheless, it is thought that $C$. yacare will always be able to coexist in sympatry with $M$. niger because it is a better colonizer able to fill the small gaps left over by the latter species (Herron 1994).

It is not clear whether the interspecific competition between the two species suggested above would be the result of differences in resource exploitation or, alternatively, the result of direct interference between individuals. Both species feed on fish, reptiles and small mammals (Vasquez 1981, Medem 1983, Micucci and Waller 1995, Aparecida Santos et al. 1996, Da Silveira and Magnusson 1999, Horna et al. 2003) but there is not much empirical evidence so far for diet overlap or resource competition in specific areas. On the contrary, Magnusson et al. (1987) and Herron (1994) suggested that the large differences in head shape between the two species may reflect different foraging strategies. Given this evidence, and giving the strong territorial behavior of $M$. niger (Medem 1983), distribution patterns are probably more affected by direct competition between this species and the smaller C. yacare.

The effect of present-day human disturbance on caiman distribution patterns: the previous discussion tried to explain caiman 
distribution patterns on the basis of factors such as historical hunting rate, microhabitat selection, interspecific competition and recovery potential. However, it should be asked as well in how far these patterns could be affected by present-day human disturbance. The results of the RTA-analysis (Fig. 4B) show that lakes very close to the river and used intensively by fishermen have a lower lagarto density than lakes at intermediate distances. A small number of $C$. yacare is removed yearly by fishermen from easily accessible oxbow lakes. Entering remote lakes in the Ichilo river floodplain requires hours of pulling canoes through densely vegetated channels, or transport of canoes through the forest, which is a reason why commercial fishermen and indigenous people prefer fishing in the more accessible lakes and streams. The number of $C$. yacare accidentally caught by fishermen between 1998 and 2000 was low and most of the individuals caught belonged to the subadult year class; smaller caimans generally passed the nets, whereas larger caimans generally escaped after destroying the nets.

Small-scale but continuous removal of $C$. yacare by fishermen may empty niches that may be occupied subsequently by black caiman. However, removal of intermediate-sized individuals by fishermen probably has only a small effect on intraspecific dominance patterns, and black caiman may not be able to take profit from this. During the present study, though fishermen are active in the area during various decades, no black caiman were found in accessible lakes.

It is not clear whether the absence of $M$. niger in accessible oxbow lakes in the Ichilo river floodplain is due to avoidance of unsuitable habitat, exclusion by previously established Caiman yacare, the result of intensive historical hunting, or whether it is caused by present-day human disturbance. The intensity of actual human disturbance is correlated with the accessibility of the different lakes and the distance of these to the river channel. However, direct mortality in the fishermen's bycatch is not the only human disturbance; Pacheco (1995) stated that black caiman are very vulnerable to the mere presence of humans. In Perú (Herron 1994) and Brazil (Thorbjarnarson 1998), where relatively healthy populations of $M$. niger remained scattered in isolated areas, particularly in oxbow lakes and other marshy, non-riverine wetlands, the relative importance of actual and historical processes was also unclear.

The present data show that the direct or indirect disturbance of $M$. niger populations in remote lakes by fishermen is low because there is little overlap between fishing areas and actual $M$. niger distribution patterns. This is exemplified by the very small number of $M$. niger captured accidentally in any year. Rebêlo and Magnusson (1983) argue that M. niger is more vulnerable to hunting pressure than $C$. crocodilus due to slower growth rates, moreover spending more time at a size range that caiman hunters prefer.

The accidental caiman catch by fishermen reflects the observed caiman distribution patterns: because fishermen mainly fish in nearby lakes, they capture mainly $C$. yacare. Fisherman's behaviour is thus an important factor to consider in the design of strategies for caiman conservation. The impact on $M$. niger populations might increase if fishermen would shift their attention to far-away lakes. If the fishermen would increase their effort in accessible lakes, they also might have more impact on $C$. yacare populations than is now the case.

Present-day cropping of Caiman yacare, made possible by Bolivian legislation, may have a more significant impact on distribution patterns of both species than fisheries activities. In the study area, legal harvesting did not take place yet, but may be planned for the near future. Removal of adult $C$. yacare from lakes may empty niches for $M$. niger, which may benefit occupying again the habitats it occupied historically. The potential impact of legal C. yacare cropping, initiated in 1999 and in the framework of which between 30000 and 40000 adult alligators are captured each year (Llobet et al. 2004), on the related M. niger is considered to be high. The impact of cropping in some areas may be that important that 
$M$. niger might be able to occupy most of its original habitat.

Conservation and management recommendations: in order to promote conservation of the caiman species it is crucial to protect some areas where there is a "surplus" population of smaller males that move out from the preferred forest lakes. In areas of extensive intact habitat or less visited by people, it is important to protect the nurseries, especially for $M$. niger (Thorbjarnarson 1998). In this sense, in the Ichilo river floodplain, it is important to take into account the differences among habitats where crocodilians are distributed. $M$. niger seems to prefer lakes with clear water and the deepest lakes generally covered by abundant machrophytes is where they can get good nesting places. Besides, these lakes are located far from the main channel. C. yacare, on the other hand, is a species that is present in all types of lakes, and it has even been found sharing the same lake with $M$. niger which could be competing by feeding and nesting resources (Magnusson 1982, Mourao et al. 1996).

The presence of indigenous communities may signify an efficient control against lake access by commercial fishermen. In the present study area, this type of local control may affect the long-term possibilities of caiman survival in the oxbow lakes on the left bank (which is part of indigenous territory). The presence of indigenous people and the difficulties of access are probably the main factors that influence the survival success of the Ichilo floodplain black caiman populations. Of the 12 studied lakes, those that contained black caiman fell within officially recognized indigenous territories. Any change in one of the mentioned factors may affect the conservation status of these vulnerable species in the future.

A careful investigation of the real impact of caiman drowning on populations may avoid charging commercial fishermen (cf. Platt and Thorbajarnarson 2000) who can otherwise play an important role in habitat conservation.

\section{ACKNOWLEDGMENTS}

We thank Milton Zapata for assistance in map interpretation. Guides from the Indigenous Territory (TCO) Yuracaré, Huascar Muñoz and Milton Zapata provided field support. This research was supported by the InterUniversity Cooperation between the San Simón University (U.M.S.S.) of Cochabamba and the University of Leuven, through the Flemish Inter-University Council (VLIR). The first author received a M.Sc. scholarship from the VLIR. One anonymous referee read earlier versions of the manuscript and provided valuable comments. Bernard Hugueny (IRD) provided orientation during the statistical analysis of caiman data. We thank Nelly de la Barra for identification of macrophyte species.

\section{RESUMEN}

Caiman yacare (lagarto) y Melanosuchus niger (caiman negro), son dos especies simpátricas para la cuenca amazónica Boliviana que han sido severamente sobreexlotadas en el pasado. El objetivo de la presente investigación es el de evaluar el estado actual de su población en doce lagunas meándricas de la planicie del río Ichilo. Se realizaron conteos nocturnos de ambas especies entre octubre y diciembre de 1999 y diciembre del año 2000. La perturbación antropogénica fue medida como el número de días por año por pescador que visitan las lagunas. El promedio de individuos observados en las orillas de las lagunas estudiadas fue de de 6 ind./km para C. yacare y de 1 ind./ km para M. Niger. Para ambas especies la población estuvo compuesta mayormente por jóvenes. Los análisis de correspondencia canónica (CCA) separaron las lagunas que se encontraron cerca del río, dominadas por $C$. yacare, de las remotas, dominadas por M. níger. El "Análisis de Árboles de Regresión" (RTA por las siglas en inglés) de ocho variables ambientales y dos antropogénicas explicó un 52.4\% de la variación de la densidad de C. yacare y un $36 \%$ de $M$. niger con la conductividad del agua. La alta conductividad coincidió con densidades mayores de C. yacare (lo opuesto para $M$. niger). Si se excluye la conductividad, la distancia de la laguna al río es el principal predictor. Factores históricos y humanos podrían estar jugando un papel importante en los patrones de distribución y abundancia de ambas especies en combinación con diferencias en la selección de habitats y/o procesos de competición exclusiva entre las dos especies. La especie $M$. niger se recupera muy lentamente de los bajos niveles de densidad poblacional 
previos y está protegida en lagunas alejadas del canal principal del Río.

Palabras clave: Amazona boliviana, caiman yacaré, planos de inundación, Melanosuchus niger.

\section{REFERENCES}

Abercrombie, C.L., C.A. Hope, J.M. Holmes, D.E Scott \& J.E Lane. 1982. Investigations into the status of the Morelet's crocodile (Crocodylus moreletii) in Belize. 1980. In Crocodiles, Proceedings of the $5^{\text {th }}$ Working Meeting of the IUCN/SSC Crocodile Specialist Group Gainesville, Florida, 11-30 IUCN, Gland, Switzerland.

Aparecida Santos, S., M. Stoli Nogueira, M. Silva Pinheiro, Z. Campos, W.E. Magnusson \& G.M. Mourao. 1996. Diets of Caiman crocodilos yacare from different habitats in the Brazilian Pantanal. Herpetol. J. 6: 111-117.

Aparicio, J., A. Llobet \& L. Pacheco. 1999. Criterios utilizados para recomendar una cuota de cosecha de Caiman yacare en Bolivia para 1999. Viceministerio de Desarrollo Sostenible y Medio ambiente, La Paz, Bolivia.

Ayarzaguena, J. 1983. Ecología del Caimán de anteojos o baba (Caiman crocodilus L.) en los llanos de Apure (Venezuela). Doñana Act. vert. No especial 10-3: 136.

Bourrel, L., S. Moreau \& L. Philips. 1999. Flood dynamics in the Bolivian Amazon basin. Rev. Bol. Ecol. Conser. Amb. 6: 5-17.

Brazaitis, P. 1989. The Caiman of the Pantanal, past, present and future. In Crocodiles, Proceedings of the $8^{\text {th }}$ working Meeting of the IUCN/SSC Crocodile Specialist Group, Quito, Ecuador, 119-124 IUCN, Gland, Switzerland.

Breiman, L., J.H. Friedman, R.A. Olshen, \& C.J. Stone. 1984. Classification and Regression Trees. Wadsworth International Group, Belmont, California, USA.

Cisneros, F \& P.A. Van Damme. 2005. Observaciones sobre la morfometría del lagarto (Caiman yacare) y del Caiman negro (Melanosuchus niger) en el TIPNIS (Bolivia). Rev. Bol. Ecol. Conserv. Amb. 18: $77-86$

Da Silveira, R. \& W. Magnusson. 1999. Diets of spectacled and black caiman in the Anavilhanos Archipelago, Central Amazonia, Brasil. J. Herpetol. 31: 514-520.

Da Silveira, R. \& J.B. Thorbjarnarson. 1999. Conservation implications of commercial hunting of black and spectacled caiman in the Mamirauá Sustainable development Reserve, Brazil. Biol. Conserv. 88: 103-109.

Ergueta, P. \& L.F. Pacheco. 1990. Los crocodilios (Orden Crocodylia) de Bolivia. Ecol. Bol. 15: 69-81.

Godshalk, R.E. 1997. Un programa de conservación del lagarto Caiman crocodilus yacare en Bolivia, con manejo para la cosecha sostenible de cueros. In Manejo de fauna silvestre en la amazonía, Instituto de Ecología, La Paz, Bolivia.

Godshalk, R.E. 1982. Status and conservation of Crocodilus intermedius in Venezuela. In Crocodiles, Proceedings of the $5^{\text {th }}$ Working meeting of the Crocodile Specialist Group IUCN/SSC, Gainesville Florida, Gland, Switzerland.

Herron, J.C. 1994. Body size, spatial distribution, and microhabitat use in the Caimans, Melanosuchus niger and Caiman crocodilus, in a Peruvian lake. J. Herpetol. 28: 508-513.

Horna, V., R. Zimmermann, R. Cintra, P. Vásquez \& J. Horna. 2003. Feeding ecology of the Black Caiman (Melanosuchus niger) in Manu National Park, Peru. Lyonia 4: 65-72.

Jongman, R.H.G., C.J.F. Ter Braak \& O.F.R. Van Tongeren. 1987. Data Analysis in community and landscape ecology. Pudoc, Wageningen, Holland.

King, F.W. \& D.W. Videz Roca. 1989. The caimans of Bolivia: A preliminary report on a CITES and Centro de Desarrollo Forestal sponsored survey of species distribution and status. In Crocodiles, Proceedings of the $8^{\text {th }}$ Working meeting of the Crocodile Specialist Group, Quito, Ecuador.

King, F.W., A.L. Aquino, N. Scott \& R. Palacios. 1994. Survey of caimans in Paraguay. In Crocodiles, Proceedings of the $12^{\text {th }}$ Working meeting of the Crocodile Specialist Group, 2:162-198 IUCN, Gland, Switzerland.

Liceaga, I., S. Ten \& M. González. 2001. Abundancia y estructura poblacional de crocodilios en la Reserva Inmovilizada Iténez (Beni, Bolivia). Rev. Bol. Ecol. Conserv. Amb. 10: 117-123.

Llobet, A. \& E. Goitia. 1997. Abundancia y estructura poblacional de Caiman yacare en lagunas de la llanura inundable de los ríos Ichilo y Chapare (Bolivia). Rev. Bol. Ecol. Conserv. Amb. 2: 39-48.

Llobet, A. \& J. Aparicio. 1999. Abundancia, estructura poblacional y perspectivas de aprovechamiento de Caiman yacare en cinco estancias del departamento 
del Beni, p. 285-293. In T. Fang, O.L. Montenegro \& R.E. Bodmer (eds.). Manejo y Conservación de Fauna Silvestre en América Latina, Institutio de Ecología, La Paz, Bolivia.

Llobet, A., L.F. Pacheco \& J. Aparicio. 2004. Analysis of the Program of Conservation and Use of the spectacled caiman (Caiman yacare) in Bolivia, and recommendations to improve it. In Proceedings of the $17^{\text {th }}$ Working Meeting of the Crocodile Specialist Group, IUCN. The World Conservation Union, Gland, Switzerland.

Maldonado, M., E. Goitia, F. Acosta, M. Cadima \& D. Castellón. 1996. Caracterización limnológica de lagunas en la Llanura Aluvial del río Ichilo, Cochabamba (Bolivia). Rev. Bol. Ecol. Conserv. Amb. 1: 29-37.

Magnusson, W.E. 1982. Biological aspects of the conservation of Amazonian Crocodilians. In Crocodiles, Proceedings of the $5^{\text {th }}$ Working Meeting of the IUCN/ SSC Crocodile Specialist Group, Gainsville Florida, 108-116 IUCN, Gland, Switzerland.

Magnusson, W.E. 1983. Size stimates of cocodrilians. J. Herpetol. 17: 86-88.

Magnusson, W.E. \& G.H. Rebêlo. 1983. Brazilian crocodiles: problems of conservation in a multispecies system. Zimbabwe Sci. News 17: 56-57.

Magnusson, W.E. 1985. Habitat selection, parasites and injuries in Amazonian Crocodilians. Amazoniana 9: 193-204.

Magnusson, W.E., E.V. Da Silva \& A.P. Lima. 1987. Diets of Amazonian crocodilians. J. Herpetol. 21: 85-95.

Medem, F. 1983. Los Crocodylia de Sur América Vol. II Venezuela, Trinidad y Tobago, Guyana, Suriname, Guayana Francesa, Ecuador, Peru, Bolivia, Brasil, Paraguay, Argentiba, Uruguay, Colciencias, Bogotá Colombia. Private edition, Bogota.

Micucci, P.A., \& T. Waller. 1995. Los yacares en Argentina: hacia un aprovechamiento sostenible. In A. Larriera \& L.M. Verdade (eds.). Fundación Banco Bica. Vol. I., Santa Fe, Argentina.

Mourao, G., Z. Campos, M. Coutinho \& C. Abercrombie. 1996. Size structure of illegally harvested and surviving Caiman, Caiman crocodilus yacare, in Pantanal, Brazil. Biol. Conserv. 75: 261-265.

Navarro, G. \& J.W. Ferreira. 2000. Caracterización ecológica y Biodiversidad de la cuenca oeste del río Ichilo (Cochabamba, Bolivia). Rev. Bol. Ecol. Conserv. Amb. 7: 3-23.
Navarro, G. \& M. Maldonado. 2002. Geografía ecológica de Bolivia: vegetación y ambientes acuáticos. Fundación Simón I. Patiño, Cochabamba, Bolivia.

Ojasti, J. 1996. Wildlife utilization in Latin America: Current status and prospects for sustainable management. FAO, Rome, Italy.

Otte, K.C. 1978. Untersuchungen zur Biologie des Mohrenkaiman (Melanosuchus niger Spix 1825) in Nationalpark Manu (Peru): Beitrage zur Morphologie, Physiolgoie, Ethologie und Ökologie, Munic, Deustland.

Pacheco, L.F. 1990. Algunos aspectos de la Biología y etologia del Melanosuchus niger en cautiverio. Tesis de Licenciatura en Biología, Facultad de Ciencias Puras y Naturales, Universidad Mayor de San Andrés, La Paz, Bolivia.

Pacheco, L.F. 1993. Abundancia, distribución y uso de habitat de Caimanes en Beni, Bolivia. M.S Thesis, University of Florida, Gainsville, Florida, USA.

Pacheco, L.F. 1996. Plan de Acción para los Caimanes de Bolivia. Ecol. Bol. 27: 43-53.

Pacheco, L.F. \& F.W. King. 1995. Perspectivas de la Conservación de Caimanes en Bolivia. In A. Larriera \& L.M. Verdade (eds.). La conservación y el manejo de caimanes y cocodrilos de america latina, Vol I Fundacion banco Bica, Santo Tomé, Santa Fé, Argentina.

Pacheco, L.F. \& J. Aparicio. 1996. Reptiles. In P. Ergueta \& C.B. de Morales (eds.). Libro rojo de los Vertebrados de Bolivia, Bolivia.

Pacheco, L.F. \& A. Llobet. 1998. Estado de las poblaciones de Caiman latirostris en Tarija, Bolivia. Rev. Bol. Ecol. Conserv. Amb. 4: 91-98.

Platt, S.G. \& J.B. Thorbjarnarson. 2000. Population status and conservation of Morelet's crocodile, Crocodylus moreletii, in northern Belize. Biol. Conserv. 96: 21-29.

Rebêlo, G.H. \& W.E. Magnusson. 1983. An analysis of the effect of hunting on Caiman crocodilus and Melanosuchus niger based on the sizes of confiscated skins. Biol. Conserv. 26: 95-104.

Rebêlo, G.H. \& L. Lugli. 2001. Distribution and abundance of tour caiman species (Crocodilia: Alligatoridae) in Jaú National Park, Amazonas, Brazil. J. Trop. Biol. 49: 1095-1109.

Rebolledo-Garín, P.P. \& M.C. Tapia-Arauz. 1994. La herpetofauna de la reserva de vida silvestre de los ríos Blanco y 
Negro: Diversidad, distribución, pautas para su conservación y uso sostenible, Informe preliminar, Fundación Amigos de la Naturaleza, FAN, La Paz, Bolivia.

Scott Jr, N.J., A. Aquino \& L.A. Fitzgerald. 1990. Distribution, habitats and conservation of the caiman (alligatoridae) of Paraguay. Vida Silv. Neotrop. 2: 43-51.

Thorbjarnarson, J. 1998. Status, ecology and conservation of crocodile (Crocodylus intermedius) in Venezuela. FUDENA. Caracas, Venezuela.

Vallejo, A., S. Ron \& E. Asanza. 1996. Growth in Melanosuchus níger and Caiman crococilus crocodilos at Zancudococha and Cuyabeno, Ecuadorian Amazon. Proc. I Workshop Meeting of the Crocodile Specialist Group, Santa Fe, Argentina.

Vasquez, R.P. 1981. Bases biológicas para el manejo de los alligatoridae en Jenaro Herrera (Requena-Perú). Tesis Universidad Nacional Agraria, La Molina, Lima, Perú.

Waller, T. \& P.A. Micucci. 1993. Relevamiento de la distribución, habitat y abundancia de los crocodilianos de la provincia de Corrientes, Argentina. In Zoocria de los crocodylia. Memorias de la $1^{\circ}$ Reunión Regional de especialistas de Cocodrilos de la UICN 341-385, Gland, Switzerland. 


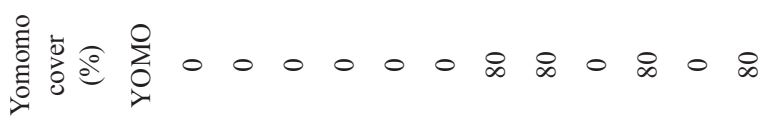

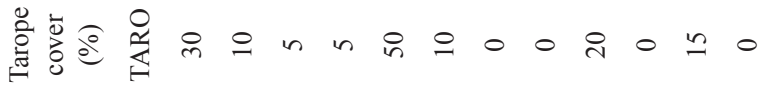

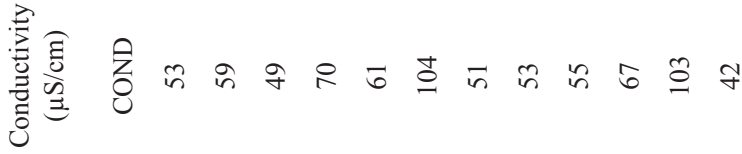

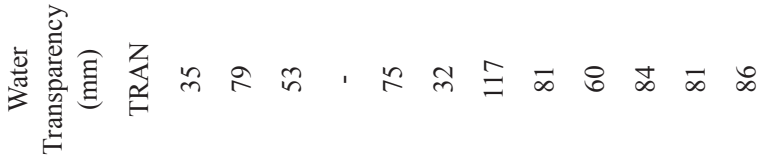

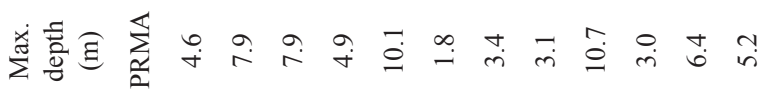

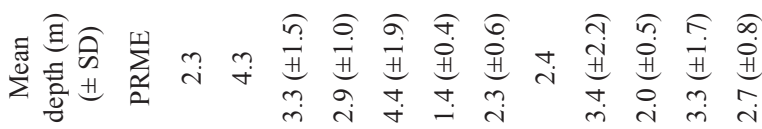

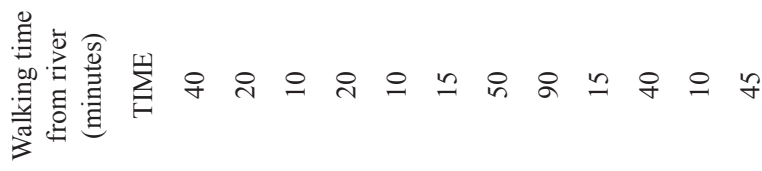

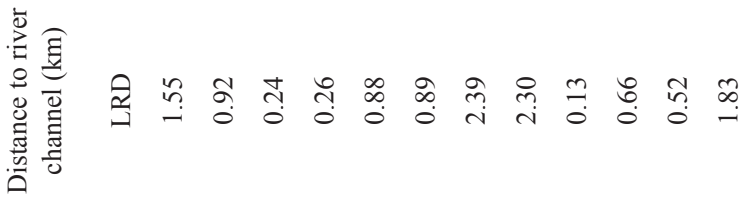

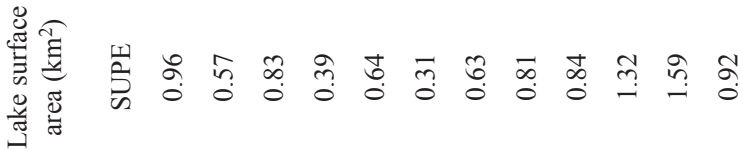

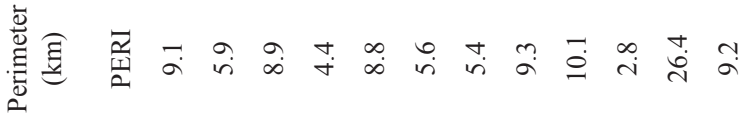

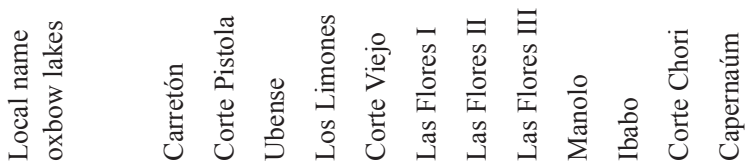

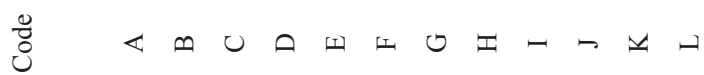


ANNEX II

Commercial Fisheries Disturbance (CFD) and Lake use by Indigenous People in the sampled oxbow lakes

\begin{tabular}{|c|c|c|c|c|c|c|c|}
\hline \multirow[t]{2}{*}{ Code } & \multirow{2}{*}{$\begin{array}{l}\text { Local names } \\
\text { Oxbow lakes }\end{array}$} & \multirow{2}{*}{$\begin{array}{l}\text { Number of canoes } \\
\text { (Variable CANO) }\end{array}$} & \multirow{2}{*}{$\begin{array}{l}\text { Path between } \\
\text { river and lake }\end{array}$} & \multicolumn{4}{|c|}{$\begin{array}{l}\text { Number of man-days fishers entered /year } \\
\text { (Variable CFD) }\end{array}$} \\
\hline & & & & 1998 & 1999 & 2000 & Total \\
\hline A & Carretón & 0 & Yes & 12 & 102 & 28 & 142 \\
\hline B & Corte Pistola & 0 & No & 5 & 32 & 0 & 37 \\
\hline $\mathrm{C}$ & Ubense & 0 & Yes & 68 & 64 & 53 & 185 \\
\hline $\mathrm{D}$ & Los Limones & 0 & Yes & 34 & 70 & 7 & 111 \\
\hline E & Corte Viejo & 0 & Yes & 63 & 117 & 25 & 207 \\
\hline $\mathrm{F}$ & Las Flores I & 2 & Yes & 0 & 4 & 0 & 4 \\
\hline G & Las Flores II & 0 & No & 0 & 0 & 0 & 0 \\
\hline $\mathrm{H}$ & Las Flores III & 1 & Yes & 0 & 0 & 0 & 0 \\
\hline I & Manolo & 0 & Yes & 0 & 11 & 5 & 16 \\
\hline $\mathrm{J}$ & Ibabo & 1 & Yes & 0 & 15 & 4 & 19 \\
\hline K & Corte Chori & 5 & Yes & 73 & 70 & 32 & 175 \\
\hline $\mathrm{L}$ & Capernaum & 1 & Yes & 0 & 0 & 0 & 0 \\
\hline
\end{tabular}

\section{ANNEX III}

Mean caiman densities for RTA classes in oxbow lakes of the Ichilo river floodplain

\begin{tabular}{|c|c|c|c|c|c|}
\hline & $\begin{array}{c}\text { RTA } \\
\text { classes }\end{array}$ & $\begin{array}{l}\text { Splitting } \\
\text { variable }\end{array}$ & Tresholds & Caiman density (ind./km) & $\begin{array}{l}\text { Explained } \\
\text { variance }\end{array}$ \\
\hline \multirow{2}{*}{ Caiman yacare } & CY1a & \multirow{2}{*}{ COND } & $<59 \mu \mathrm{S} / \mathrm{cm}$ & $3.88( \pm 2.10 \mathrm{SD})(\mathrm{N}=5)$ & \multirow{2}{*}{$52.4 \%$} \\
\hline & $\mathrm{CY} 2 \mathrm{a}$ & & $>59 \mu \mathrm{S} / \mathrm{cm}$ & $9.42( \pm 3.51 \mathrm{SD})(\mathrm{N}=6)$ & \\
\hline \multirow[b]{3}{*}{ Caiman yacare } & CY1b & \multirow[b]{3}{*}{ LRD* } & $\mathrm{LRD}<0.66 \mathrm{~km}$ & $5.94( \pm 2.82 \mathrm{SD})(\mathrm{N}=4)$ & \multirow{3}{*}{$\begin{array}{c}27.4 \% \\
\text { (at splitting threshold } \\
\mathrm{LRD}=1.55 \mathrm{~km} \text { ) } \\
33.9 \% \text { (at splitting } \\
\text { threshold } \\
\mathrm{LRD}=0.66 \mathrm{~km} \text { ) }\end{array}$} \\
\hline & $\mathrm{CY} 2 \mathrm{~b}$ & & LRD $0.66-1.55 \mathrm{~km}$ & $10.19( \pm 3.94 \mathrm{SD})(\mathrm{N}=4)$ & \\
\hline & CY3b & & $\mathrm{LRD}>1.55 \mathrm{~km}$ & $3.82( \pm 2.66 \mathrm{SD})(\mathrm{N}=4)$ & \\
\hline \multirow{2}{*}{ Melanosuchus niger } & MN1 & LRD & LRD $<1.55 \mathrm{~km}$ & $0.00( \pm 0.00 \mathrm{SD})(\mathrm{N}=8)$ & \multirow{2}{*}{$52.6 \%$} \\
\hline & MN2 & LRD & LRD $>1.55 \mathrm{~km}$ & $2.88( \pm 2.58 \mathrm{SD})(\mathrm{N}=4)$ & \\
\hline
\end{tabular}

*Analysis conducted after excluding the variables COND and TARO from the analysis. 